UDC 621.396

\title{
RESEARCH AND IMPLEMENTATION OF IOT PROJECTS FOR ENVIRONMENT PARAMETERS AND ENERGY RESOURCE METERING
}

\author{
${ }^{1}$ Leonid O. Uryvsky, ${ }^{2}$ Wolfgang H. Gerstacker, ${ }^{1}$ Alina V. Moshynska, ${ }^{1}$ Serhii O. Osypchuk, \\ ${ }^{1}$ Oleksandr V. Yatsyshyn \\ ${ }^{1}$ Institute of Telecommunication Systems \\ Igor Sikorsky Kyiv Polytechnic Institute, Kyiv, Ukraine \\ ${ }^{2}$ Department of Electrical, Electronic and Communication Engineering \\ Friedrich-Alexander-University of Erlangen-Nürnberg, Erlangen, Germany
}

Background. IoT is a modern trend and the need of today's World and people. Two solutions are considered in current paper actual for Ukraine needs.

Objective. The aim of the paper is to design, build and test the practical and cost-effective IoT solutions for Ukraine needs that could be useful for rest of the world.

Methods. Analysis, synthesis, generalization, experiment, measurement.

Results. The paper presents research and practical implementation results of the Internet of Things (IoT) projects for automated collection of temperature values, and automated data gathering with text recognition from resource meters (water, electricity, etc.). The projects are implemented at Telecommunication Systems department of Institute of Telecommunication Systems.

Conclusions. The received results can be useful for wide IoT industrial-size implementations in Ukraine and countries all over the world.

Keywords: IoT; environment parameters metering; energy resource metering; automation; IEEE 802.11; OCR; ESP8266; ESP32; Tesseract.

\section{INTRODUCTION}

One of good definitions for Internet of Things (IoT) [1-3] is the following: IoT is a network of physical devices equipped with sensors, electronics, software, communication technologies, to interact with one another or with external environment, designed and built for purpose of restructuring economic and social processes and eliminating the need of human participation which leads to increased efficiency and reduced human workloads.

The IoT is one of the fastest growing and most promising technologies. The world's leading companies in the field of IT, electronics, telecommunications such as Samsung, LG, Apple, Google, Lowe's and Philips, etc. are working on IoT products. Like many other small companies and startups, they work on the development and production of IoT devices. According to Statista Research Department report [3], the total installed base of the IoT connected devices is projected to amount to 75.44 billion worldwide by 2025 , a fivefold increase in ten years. Number of IoT connected devices installed base worldwide from 2015 to 2025 is shown on Fig. 1 (in billions).

Vodafone highlights that today more than one-third of companies use IoT solutions to optimize processes, reduce operating costs, improve data collection, create new revenue streams or increase revenue from existing ones [4].

All above are general World IoT trends. The same trends are effective for Ukraine as well, while there is some delay in couple years for Ukraine to follow and implement the latest IoT solutions or technologies. At the same time, from country to country across the World, the needs of IoT implementation do differ. The designed testbed solution for resource metering presented in this paper - is a great example of such differences. However, this solution is clearly not mandatory and maybe is not actual for many countries across the World, while is beneficial in Ukraine in particular.

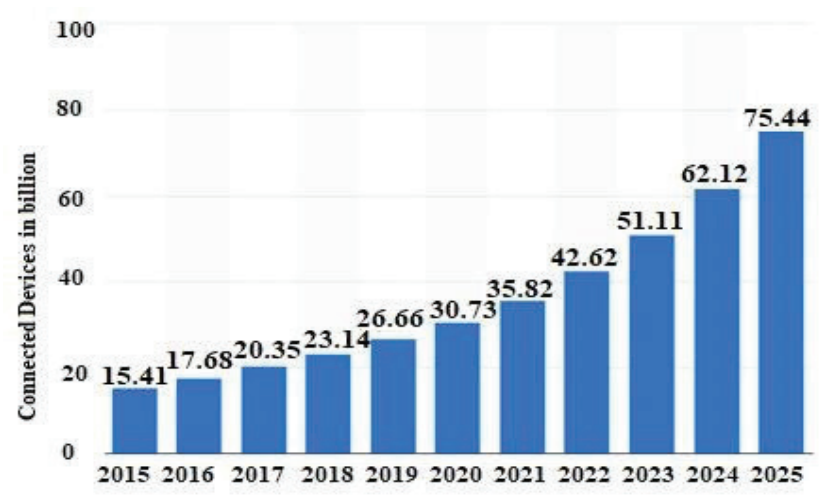

Fig. 1. Number of IoT connected devices installed base worldwide from 2015 to 2025 (in billions) 


\section{IOT DEVELOPMENT IN UKRAINE}

The areas of IoT application in Ukraine are diverse, such as transport, health care, medicine, manufacturing, agriculture, smart homes and cities, nature, agriculture, to name a few. In this case, customers can be and are both individuals and legal entities, respectively, depending on the scope of IoT.

It is important to note that today in Ukraine there are some locally implemented IoT projects for different consumers (for example, a smart home - for individuals, a smart city - some services such as gas stations, parking, etc.), but there is no comprehensive provider IoT services for any consumer that the IoT provider could satisfy on all requests and provide a comprehensive solution of services in Ukraine (and even in any city), not to mention the guaranteed support and provision of services by IoT service provider or by involving third parties if necessary. These facts show that IoT development in Ukraine is at a very early stage and much has not been done in the direction of wide range IoT services quality implementation in Ukraine.

First of all, it is necessary to understand that IoT technologies bring significant optimization of resources and cost savings, - for example, utilities. It automates the process of collecting data from various sensors, be it water meters, heat meters, and other types of energy metering. With such a tool, utilities, for example, can obtain detailed information on costs, uncollected funds and analyze these data, making forecasts for the purchase of quotas for heat, electricity and others.

IoT application Areas in Ukraine. Due to the widespread use of IoT in various fields, it is possible to classify services and areas of IoT application which allow more accurately determine the technical system requirements for relevant IoT services provision. Examples:

- Monitoring of industrial facilities:

- Temperature control

- Pressure control in fuel tanks

- Identification of substance leakage

- Vibration control

- Optimization of energy consumption

- Control of sensors for water, gas and electricity meters

- Applications in cities:

- "Smart" city

- $\quad$ "Smart" parking

- Monitoring of all free / occupied parking spaces

- Network of gas stations

- Monitoring of public transport

- Taxi service

- $\quad$ "Smart" house:

- Temperature control

- Control of smoke sensors

- Identification of water leakage

- Optimization of energy consumption

- Agricultural complex:

- Temperature monitoring

- "Smart" watering
- Tracking the location of animals

- Soil moisture control

- Vehicle monitoring

- Cargo transportation

- Health care:

- Sensors for monitoring the health of patients

- Remote monitoring and transmission of health data

This list can go on indefinitely - but its purpose is to show that there are many industries and areas of IoT technologies application in Ukraine and the world, and currently in Ukraine such applications and services are in the early stages of implementation and can be optimized in order to improve the quality of life and save resources.

\section{Problem STATEMENT}

The officially approved students' circle of interests "Researchers of wireless technologies for information transmission in the IoT systems" operates in the Telecommunication Systems Department of Telecommunication Systems Institute since it was established in 2018. This students' circle covers both research of building IoT systems theoretical aspects and relevant information transfer technologies, as well as practical implementation of IoT projects.

Two tasks and problems are solved in this work, with aim to minimize any human involvement to data gathering and analysis:

- the need to involve significant human resources to measure and record information on a regular basis about temperature in the lecture rooms of Telecommunication Systems Institute educational building for further data analysis and temperature control,

- automated data gathering about the used resources in buildings (water, electricity, heat supply) with old metering devices that do not transmit data about the amount of used services to data processing centers.

The tasks are solved, and testbeds built for mentioned problems above that are expanded in details below.

\section{TELECOMMUNICATION LEVELS AND TASKS}

Considering the components of the existing IoT architectures, the key steps and components of any IoT solution can be split to telecommunication levels and tasks that are being solved on those levels (Table 1).

Table 1. Key levels and objectives of IoT

\begin{tabular}{|c|c|c|}
\hline \# & $\begin{array}{c}\text { Telecommunication } \\
\text { level }\end{array}$ & $\begin{array}{c}\text { Tasks that are solved } \\
\text { on the level }\end{array}$ \\
\hline 1 & $\begin{array}{l}\text { Information collection } \\
\text { from IoT objects }\end{array}$ & $\begin{array}{l}\text { - Conversion of the sensor } \\
\text { response into a signal } \\
\text { - Signal transmission to the } \\
\text { nearest transportation node } \\
\text { (IoT hub, router, etc.) }\end{array}$ \\
\hline
\end{tabular}




\begin{tabular}{|c|l|l|}
\hline 2 & $\begin{array}{l}\text { Information } \\
\text { transportation to } \\
\text { decision points }\end{array}$ & $\begin{array}{l}\text { - Information transfer from the } \\
\text { information collection node } \\
\text { (for example, IoT hub) to the } \\
\text { point of centralized } \\
\text { information collection, } \\
\text { analysis, statistical processing } \\
\text { and decision making }\end{array}$ \\
\hline 3 & $\begin{array}{l}\text { Information } \\
\text { transportation after } \\
\text { decision making }\end{array}$ & $\begin{array}{l}\text { - Information transmission to } \\
\text { interested or other relevant } \\
\text { stakeholders or services for the } \\
\text { purpose of informing or } \\
\text { guiding for an action - to } \\
\text { respond to the data from IoT } \\
\text { device }\end{array}$ \\
\hline
\end{tabular}

The implemented two practical solutions in this work include first two layers.

\section{IOT TEMPERATURE Metering SOLUTION IMPLEMENTATION}

Since the automated temperature data collection had to be implemented in the educational building with $220 \mathrm{~V}$ power supply and with the ability to connect via WiFi IEEE 802.11 access points to Internet, the decision was made to use these available resources to build a cost-effective solution, i.e. less expensive and without involving to the solution any additional power sources and without any additional information transfer technologies.

The data from these temperature sensors are transmitted to the MySQL database hosted on the Internet. The scheme of the implemented solution with two temperature sensors is shown on Fig. 2

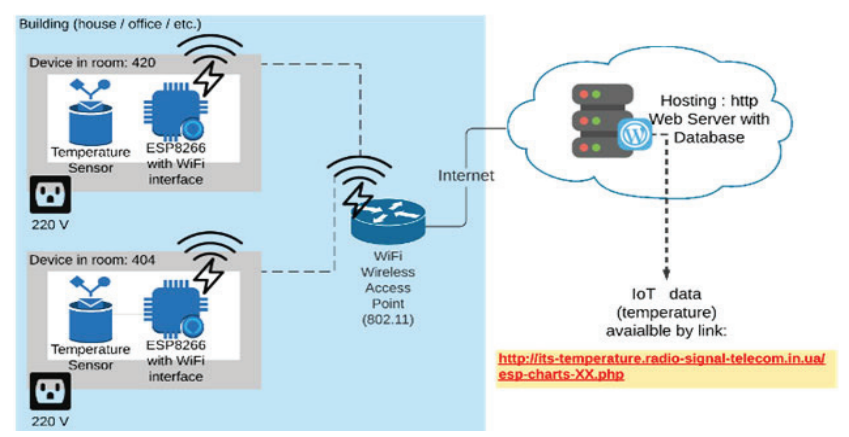

Fig. 2. High-Level scheme of implemented IoT project for automated temperature data collection

Fist telecommunication level, information collection from IoT objects, is based on the temperature sensors models DHT11, DHT21, DHT22 [5]. These sensors connect to the NodeMCU V3 ESP8266 (CP2102) transceivers [6] that have built in wireless WiFi module (IEEE 802.11). The DHT temperature sensors with the ESP8266 board are mounted to a plastic box with intentionally made holes for ventilation and precise temperature measurement.

The sensors and transceivers boards are shown on Fig. 3. Sensor attached to transceiver and mounted in plastic box is shown on Fig. 4, as well as a full designed and developed device for measuring and transmitting temperature values.

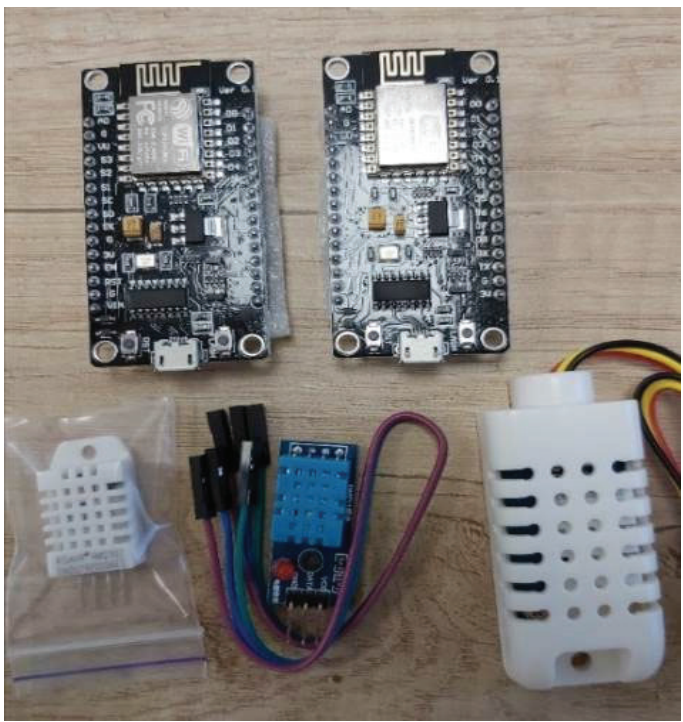

Fig. 3. Sensors and transceivers boards
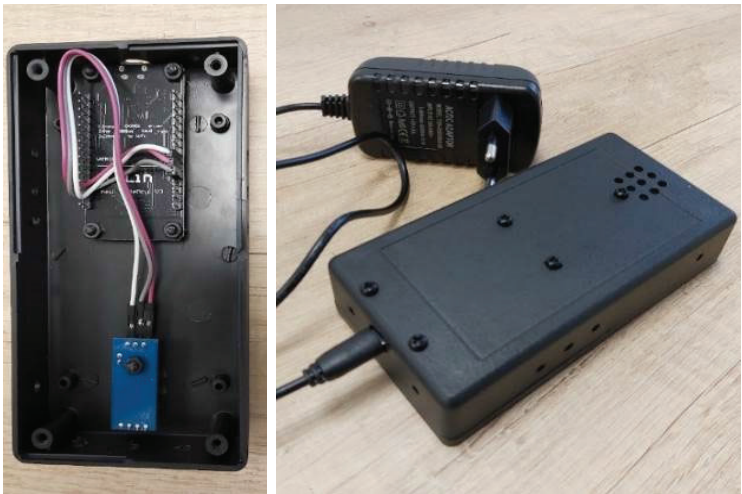

Fig. 4. Sensor attached to transceiver and mounted in plastic box and full designed and developed device for measuring and transmitting temperature values

The DHT11 temperature sensor characteristics [5]: temperature determination in range of $0-50{ }^{\circ} \mathrm{C}$ with error deviation of $2^{\circ} \mathrm{C}$, response frequency $<1 \mathrm{~Hz}$, dimensions 15.5 $\mathrm{x} 12 \times 5.5 \mathrm{~mm}$

The NodeMCU V3 ESP8266 transceiver characteristics [6]: protocols WiFi $802.11 \mathrm{~b} / \mathrm{g} / \mathrm{n}$; built-in TCP/IP stack; digital and analog inputs D0-D8, SD1-SD3, AD0; power: $3.3-5 \mathrm{~V}$; power consumption: data exchange: $70 \mathrm{~mA}$ (200 mA maximum), standby time: $<200 \mathrm{~mA}$; board sizes $48 \times 26 \mathrm{~mm}$; operating temperature $-40 \ldots+125^{\circ} \mathrm{C}$.

To be able to send temperature data from the ESP8266 board, the necessary program code was created to program the ESP8266 board. Temperature data is written to relational MySQL to the Internet using Web technologies (HTML, 
PHP). A web page based on HTML \& PHP was created [7] to read data from database and visualize it. Graph with measured temperature is shown on Fig. 5, and is accessible worldwide via link [7].

\section{Room: 406}
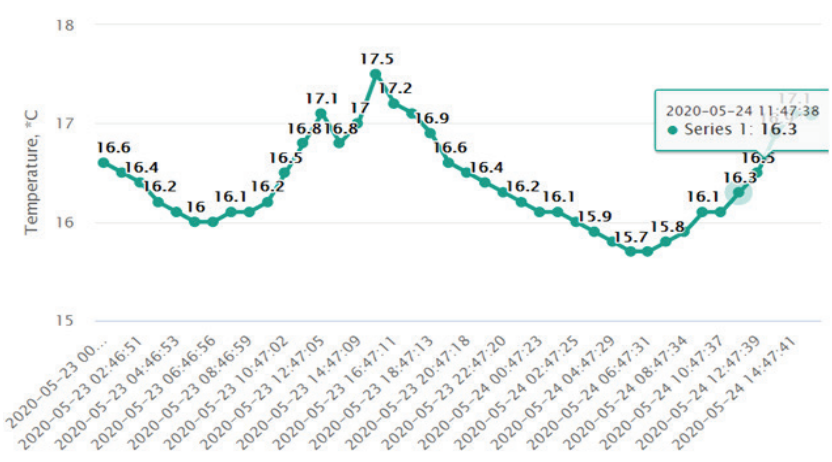

Fig. 5. The graph with temperature data visualization from one sensor. He Web page is designed to show data from multiple sensors

The IoT project is implemented for automated temperature collection, which solves the task of freeing human resources from manual temperature measurement. The 5 devices have been developed so far which are set up in the classrooms \#403, 404, 406, 420, 503 of Telecommunication Systems Institute. Devices transmit temperature data values to MySQL database hourly, and data is visualized on the Web page [7]. The implemented IoT project allows a flexible extension of devices number to hundreds+, as well as allows devices extension by other sensor types (e.g., air quality, smoke, etc.).

The working group with the main contributors is shown on Fig. 6: Oleksandr Iatsyshyn, Andrii Maltsev, Artem Dykyi, and others who are not shown on this photo.

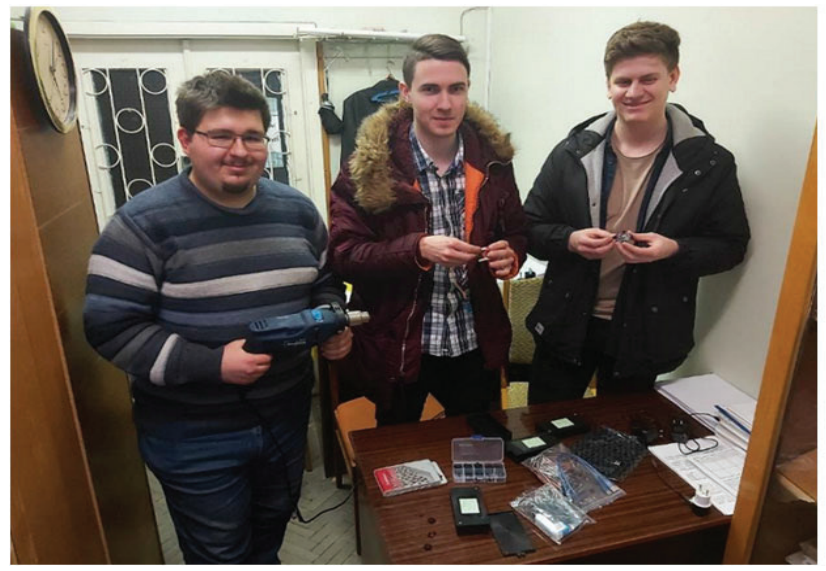

Fig. 6. The working group of temperature metering solution implementation

So, the actual and cost-effective solution is designed and built for environment parameters metering.

\section{IOT ENERGY RESOURCE METERING SOLUTION IMPLEMENTATION}

As was already stated at the beginning of paper, the reality in Ukraine is that almost all buildings, be it civil or industrial (except some numbers of the newest built last 1-3 years) have the resource metering devices without any interfaces for data transfer to data processing centers. That means two major things: 1) the need of manual gathering such data in asynchronous mode, and 2) the problem of delay with such data gathering and bills calculation.

The solution for this issue could be either 1) to replace of the old resource metering devices with new resource metering devices that have some interface for data transmission, or 2) to design and enable some workaround for gathering data automatically rather than manually without intervention to the existing resource metering devices (e.g. to avoid physical replacement of old devices with new ones).

As was figured out, the first solution is cost expensive and requires a lot of paperwork with respective bureaucracy. The second solution looks much more flexible while is not widely enabled yet, so that's why decision was made to work on such IoT solution - to design and implement a testbed for automated data gathering without human manual action.

The Tesseract software [8-9] is used for the designed and developed solution. Tesseract is an optical character recognition (OCR) engine for various operating systems. It is free software, released under the Apache License. Originally developed by Hewlett-Packard as proprietary software in the 1980 s, it was released as open source in 2005 and development has been sponsored by Google since 2006. In 2006, Tesseract was considered one of the most accurate open-source OCR engines then available.

The high-level diagram of solution \#2 is shown on Fig. 7. From the top to the bottom:

- The water meter with a drum counter that shows the used water amount,

Camera that takes a photo of water meter at specific moment of time,

Transceiver ESP32 [10] with WiFi interface that receives the photo from camera, saves into the file and send it to the server for optical character recognition (OCR) processing,

Telecommunication infrastructure that plays a middleman role for data transmission between the transceiver and OCR processing center (the $\mathrm{WiFi}$ access point is used for testbed),

OCR processing center that processes photos and stores the data in proper form (text or database). For the testbed, the Raspberry Pi 3 Model B [11] with Tesseract libraries are used [8-9]; any machine learning / python libraries or other tools can be used to improve test recognition,

Data consumers who are either the end users or 3rd parties that respond to data from resource meters. 


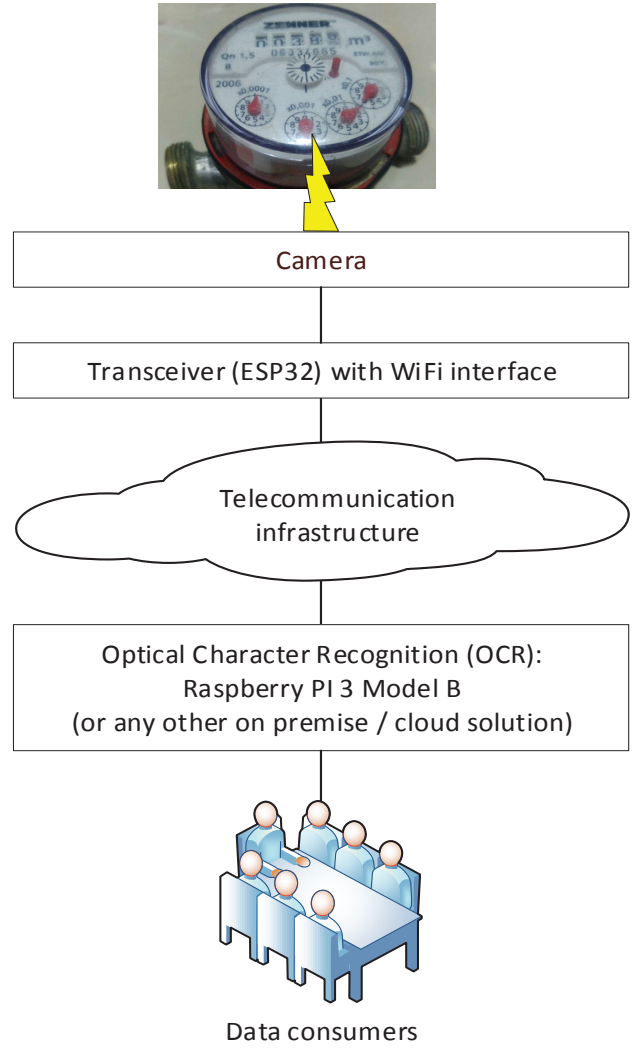

Fig. 7. IoT energy resource metering solution high-level diagram

The student who contributed the most to this project is Daniil Matiushenko - graduated from institute of telecommunication systems in late 2019, Fig. 8.

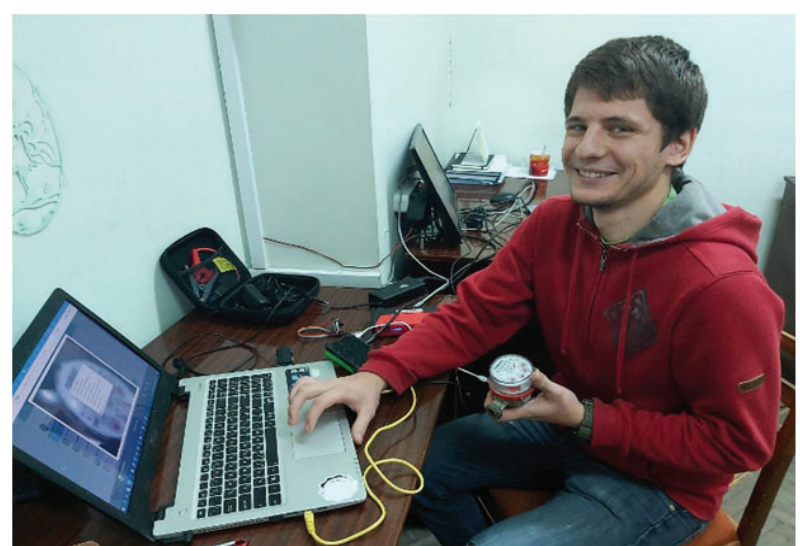

Fig. 8. The project in progress. Daniil Matiushenko is building the IoT automated water metering solution
The photo of testbed water meter is shown on Fig. 9. It's the device with water in/our caves and digits drum that shows the amount of used water, cubic meters.

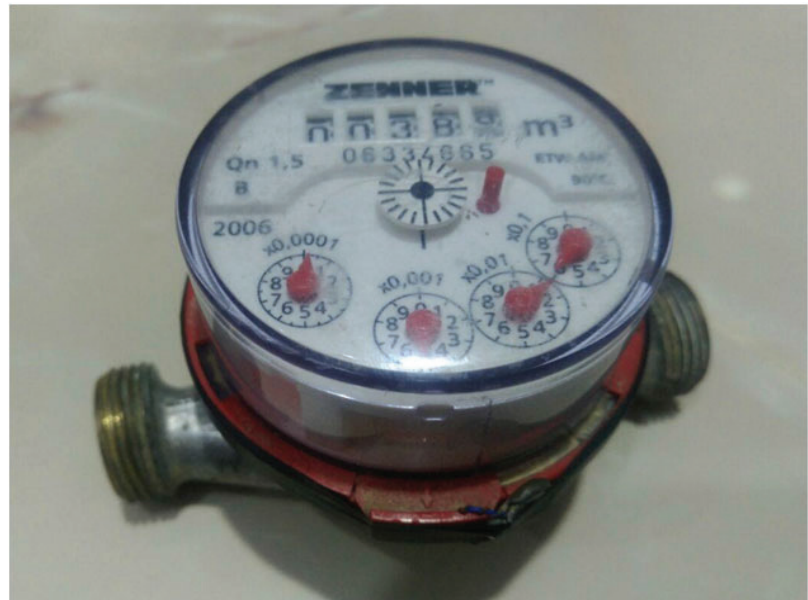

Fig. 9. The water meter

The complexity of solution is the digits recognition from the water meter: digits could be not fully shown or shown just in the middle between two digits, the photo quality might ont good, etc. - so there is the need coming of both making a qualitative photo and algorithms for text recognition (OCR, $\mathrm{ML}$, different libraries, etc.). The photo example from water meter is shown on Fig. 10.

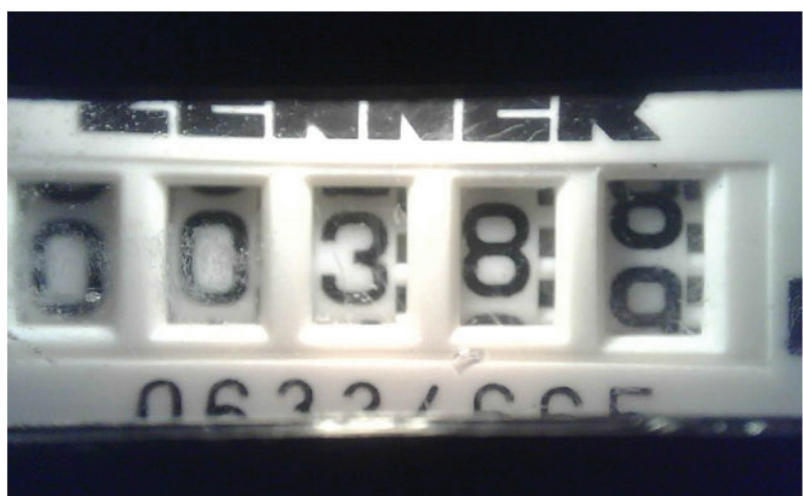

Fig. 10. The digits from water meter that need text reognition

Anther task in scope of this solution was to fasten the camera on the water meter - because the meters are very different: sizes, form-factors, required distance between camera and meter, etc. For this purpose, the model was developed and printed on 3D printer for fastening camera on the water meter on specific distance from the digits to make a good quality photo, Fig. 11. 


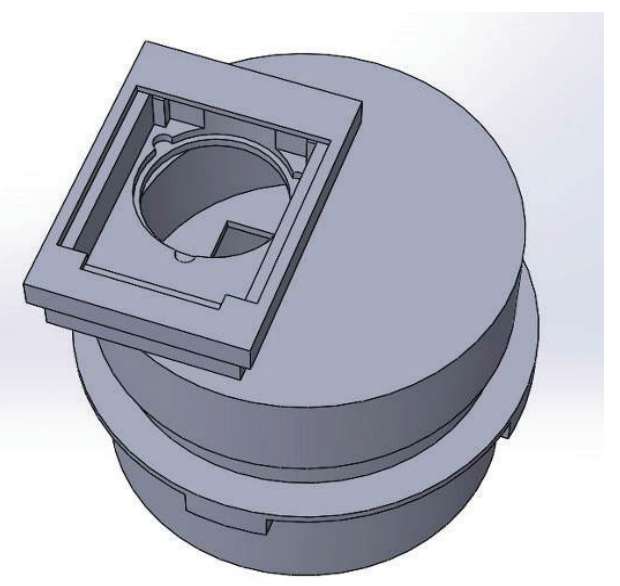

Fig. 11. The box model for fastening the camera on the water meter

Finally, the assembly of water meter and the designed \& printed box with holding the camera and ESP32 transmitter is shown on Fig. 12.

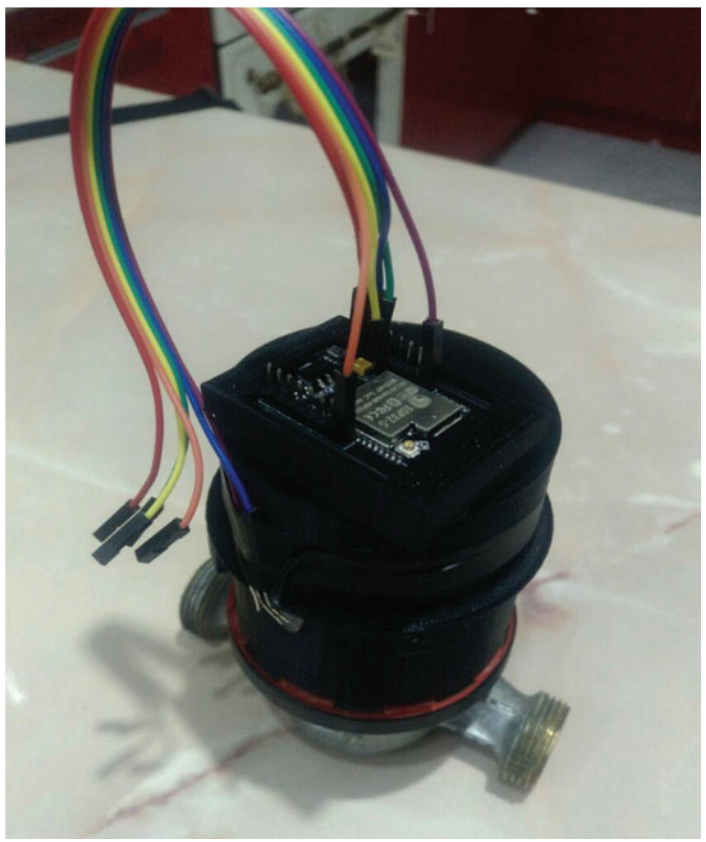

Fig. 12. Assembly of water meter and the designed \& printed box with holding the camera and ESP32 transmitter

The OCR processing center that processes photos and stores the data in proper form (text or database) is designed based on the Raspberry Pi 3 Model B with Pytesseract libraries for OCR purposes. Other solutions for this task could be any avaiable cloud solutions (e.g. Google) that provide API for OCR purposes, but that could be next step of improvement and solution scalability while for testbed it was enough to use the power of Raspberry PC (Fig. 13).

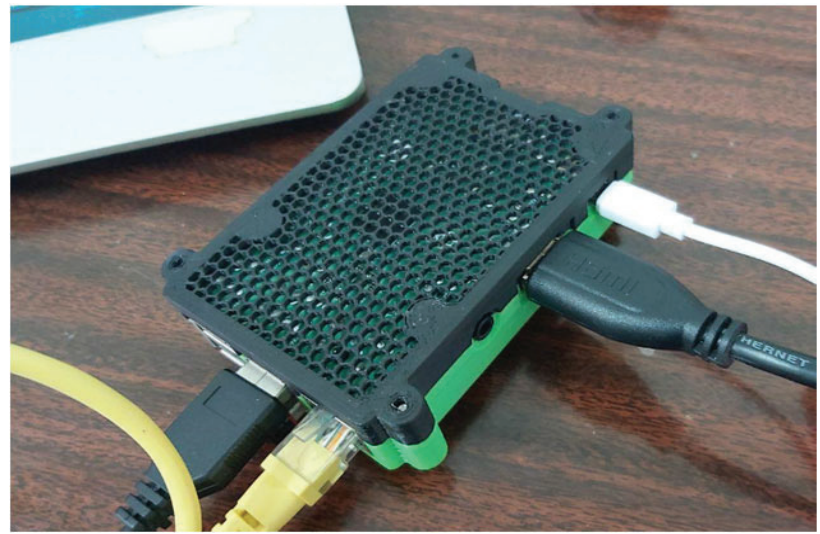

Fig. 13. Raspberry Pi Model B as the OCR processing center with Pytesseract software

Finally, the program that gets the digits from photo file to text format, include the following steps:

- Inverts the image,

- Processes image by color and converts image to black and white,

- Reduces photo size for faster processing,

- Enables a blur effect to reduce noise,

- Runs a Tesseract with certain selected parameters,

- Creates and saves a text file with recognized characters.

The Python code example looks like this one:

import pytesseract

from PIL import Image

import cv2

im = Image.open ('5.jpg')

im.transpose(Image.ROTATE_180).save('6.jpg'

img = cv2.imread ('6.jpg', cv2. IMREAD COLOR)

\#Open the image from which the charactēers has to be recognized

\#img = cv2.resize(img, $(620,480)$ ) \#resize the image if required

gray $=\quad$ cv2.cvtColor(img,

cV2 COLOR BGR2GRAY) \#convert to grey to reduce details

gray = cv2.bilateralfilter(gray, 11, 17,

17) \#Blur to reduce noise

original

pytesseract.image_to_string(gray, config='-1 eng --oem 3 --psm $10 \bar{'}$ )

\#test = (pytesseract.image_to_datalgray, lang=None, config='', nice=0) ( \#get

confidence level if required

\#print (pytesseract.image_to_boxes (gray))

my file = open (original+".txt", "w") 
my file.close()

print (original)

From the solution next possible improvements perspective, the algorithms and software code for text recognition can be improved and usually should be adapted for each specific metering device - due to different design of monitor / digits drum and such other constructive specifics.

So, the practical solution is developed with testbed and shown for energy resource metering implementation to automatically gather the resource usage data and processing that in data processing center.

\section{CONCLUSION}

The IoT direction is developing rapidly in the world today and is increasingly penetrating the field of human activity, with the goal of simplifying the collection of information, automating the response to information received, and, ultimately, leading to increased economic efficiency and reduced human workloads. Such development has already largely affected Ukraine.

The paper describes the process of practical implementation of the IoT solution for temperature values gathering based on the ESP8266 microcontrollers. The data read by the sensor is easily accessible from any part of the planet where there is Internet via Web-page. The proposed solution can be applied in any residential, educational building, or in production where temperature indicators are important. Also, the implementation can be easily scalable with an increase in the number of sensors, or with the introduction of sensors of a different type.

Another implemented project is the automated data gathering from resource meters (water, electricity, etc.) that excludes human actions: takes a photo from meters (camera and transceiver ESP32), submit data to data processing center via telecommunication infrastructure, extracts text from photo to text in processing center (implemented based on Raspberry Pi 3 Model B with Tesseract open source software), and saves data to text format or to database. The benefit of solution is that there is no need to make any changes for existing resource meters and apply just some extension modules on them to take photos from and send to data processing center.

In the designed solutions, IEEE 802.11 technology was used as the data transmission technology. Depending on the requirements, this solution can be easily transformed to use any other proper wireless or wired technology.

\section{REFERENCES}

1. IoT on Wikipedia. [Online] Available: https://en.wikipedia.org/wiki/Internet_of thing

2. IoT Communication Technologies Guidebook. [Online]. Available: https://www.postscapes.com/internet-of-things-technologies

3. Internet of Things (IoT) connected devices installed base worldwide from 2015 to $2025 . \quad$ [Online] Available: https://www.statista.com/statistics/471264/iot-number-ofconnected-devices-worldwide

4. Vodafone Start Smart Metering [Online]. Available: https://www.vodafone.ua/ru/news/vodafone-start-smart-metering

5. Sensor DHT11. [Online]. Available: https://arduino.ua/prod185datchik-vlajnosti-i-temperatyri-dht11
6. Transceiver [Online]. ESP8266. Available: https://arduino.ua/prod1492-wi-fi-modyl-nodemcu-esp8266

7. Visualization of the collected temperature data based on the Institute of Telecommunication Systems. [Online]. Available: http://itstemperature.radio-signal-telecom.in.ua/esp-charts-XX.php

8. An Overview of the Tesseract OCR Engine. [Online]. Available: https://static.googleusercontent.com/media/research.google.com/en/ pubs/archive/33418.pdf

9. Tesseract [(software) Anline]. Available: https://en.wikipedia.org/wiki/Tesseract_(software).

10. ESP32-CAM Review. [Online] https:/hackspace.raspberrypi.org/articles/esp32-cam-review

11. Raspberry $\mathrm{Pi} 3$ Model B review. [Online]. Available: https://www.pcworld.com/article/3396158/raspberry-pi-3-breview.html

12. Uryvsky L.O., Osypchuk S.O., Moshynska A.V. Internet Of Things Solutions Research And Development For Widespread Usage And Applications / The Actual Problems of the World Today/ monograph. - London, SCIEMCEE (2019) - pp. 254-266.

13. Uryvsky L., Moshynska A., Osypchuk S., Kyrashchuk V. IoT solutions research and development for wide range applications / Sciences of Europe, Praha, Czech Republic. Vol.1, No 36 (2019). p.p. 40-54. http://europe-science.com/wpcontent/uploads/2019/03/VOL-1-No-36-2019.pdf.

14. Uryvsky L.O., Osypchuk S.O. Conceptual aspects of the IoT networks organization in Ukraine / High technology in information and telecommunications: information processing, cybersecurity, information warfare. Monograph. V.M. Bezruk, V.V. Barannyk Kharkiv: Kharkiv: FOP Brovin O.P., 2018 .-- p. 89-112. 
Уривський Л.О., Геритакер В.Х., Яцишин О.В., Осипчук С.О.

Дослідження та реалізація ІоТ проектів для вимірювання параметрів навколишнього середовища та обліку енергоресурсів

Проблематика. ІоТ - це сучасна тенденція та потреба сучасного світу та людей. В даній роботі розглянуто два рішення, які є актуальними для потреб України.

Мета дослідження. Метою роботи є розробка, побудова та перевірка практичних та економічно ефективних рішень ІоТ для потреб України, які можуть бути корисними також для решти світу.

Методика реалізації. Аналіз, синтез, узагальнення, експеримент, вимірювання.

Результати дослідження. У статті представлені результати досліджень та практичних результатів впровадження проектів Інтернету речей (IoT) для автоматизованого збору температурних значень та автоматизованого збору даних із розпізнаванням тексту 3 лічильників ресурсів (вода, електроенергія, тощо). Проекти реалізовані на кафедрі телекомунікаційних систем Інституту телекомунікаційних систем.

Висновки. Отримані результати можуть бути корисними для широких впроваджень ІоТ промислового розміру в Україні та інших країнах світу.

Ключові слова: IoT; вимірювання параметрів середовища; облік енергоресурсів; автоматизація; IEEE 802.11; OCR; ESP8266; ESP32; Tesseract.

Урывский Л.А., Геритакер В.Х., Яцишин А.В., Осипчук С.А.

Исследование и реализация ІоТ проектов для измерения параметров окружающей среды и учета энергоресурсов

Проблематика. ІоТ - это современная тенденция и потребность современного мира и людей. В данной работе рассмотрены два решения, которые актуальны для нужд Украины.

Цель исследования. Целью работы является разработка, построение и проверка практических и экономически эффективных решений ІоТ для потребностей Украины, которые могут быть полезными также для остального мира.

Методика реализации. Анализ, синтез, обобщение, эксперимент, измерение.

Результаты исследования. В статье представлены результаты исследований и практических результатов внедрения проектов Интернета вещей (IoT) для автоматизированного сбора температурных значений и автоматизированного сбора данных с распознаванием текста со счетчиков ресурсов (вода, электроэнергия и т.д.). Проекты реализованы на кафедре телекоммуникационных систем Института телекоммуникационных систем.

Выводы. Полученные результаты могут быть полезными для широких внедрений ІоТ промышленного размера в Украине и других странах мира.

Ключевые слова: IoT; измерения параметров среды; учет энергоресурсов; автоматизация; IEEE 802.11; OCR; ESP8266; ESP32; Tesseract. 